\title{
Polyphosphate Functions In Vivo as Iron Chelator and Fenton Inhibitor
}

\author{
Francois Beaufay $^{\mathrm{a}^{*}}$, Ellen Quarles ${ }^{\mathrm{a}}$, Allison Franz ${ }^{\mathrm{a}}$, Olivia Katamanin ${ }^{\mathrm{a}}$, Wei-Yun Wholey ${ }^{\mathrm{a}}$, and \\ Ursula Jakob ${ }^{\mathrm{a}, \mathrm{b}^{* *}}$
}

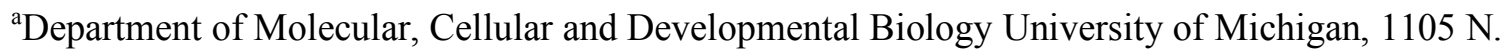

University Ave, Ann Arbor, MI 48109, USA

${ }^{\mathrm{b}}$ Department of Biological Chemistry University of Michigan, Ann Arbor, MI 48109, USA

"present address: Cellular and Molecular Microbiology (CM2), Faculté des Sciences, Université Libre de

Bruxelles (ULB), Gosselies, Belgium

*Corresponding author:

Ursula Jakob

5014 BSB, 1105 N. University Avenue, Ann Arbor, MI 48109-1085

ujakob@umich.edu

(734) 615-1286

Running title: PolyP Functions as Fenton Inhibitor 


\begin{abstract}
Maintaining cellular iron homeostasis is critical for organismal survival. Whereas iron depletion negatively affects the many metabolic pathways that depend on the activity of iron-containing enzymes, any excess of iron can cause the rapid formation of highly toxic reactive oxygen species (ROS) through Fenton chemistry. Although several cellular iron chelators have been identified, little is known about if and how organisms can prevent the Fenton reaction. By studying the effects of cisplatin, a commonly used anticancer drug and effective antimicrobial, we discovered that cisplatin elicits severe iron stress and oxidative DNA damage in bacteria. We found that both of these effects are successfully prevented by polyphosphate (polyP), an abundant polymer consisting solely of covalently linked inorganic phosphates. Subsequent in vitro and in vivo studies revealed that polyP provides a crucial iron reservoir under nonstress conditions, and effectively complexes free iron and blocks ROS formation during iron stress. These results demonstrate that polyP, a universally conserved biomolecule, plays a hitherto unrecognized role as an iron chelator and an inhibitor of the Fenton reaction.
\end{abstract}




\section{Introduction}

Cisplatin (cis-diaminedichloroplatinum (II)), originally identified as an inducer of bacterial filamentation (Rosenberg et al., 1965), is one of the most widely used drugs in cancer treatment (Galanski et al., 2005, Hannon, 2007). Early mechanistic studies suggested that cisplatin elicits cytotoxicity by acting as a DNAdamaging agent, preferentially crosslinking neighboring purines (Bancroft et al., 1990, Eastman, 1987, Sherman \& Lippard, 1987). More recent studies, however, revealed that cisplatin also induces cell death in denucleated cells by causing mitochondrial and endoplasmic reticulum stress (Mandic et al., 2003, Yang et al., 2006). Indeed, only a small fraction of the intracellular cisplatin pool appears to reach the nucleus, whereas the vast majority binds to the sulfur-containing side chains in proteins as well as to thiol-containing compounds (Ishikawa \& Ali-Osman, 1993, Karasawa et al., 2013, Lin et al., 2002, PelegShulman et al., 2002). Studies in mouse models and ovarian cancer cell lines revealed that tumorous cells gain resistance against cisplatin by increasing their levels of cysteine-enriched peptides (i.e., glutathione) and proteins (i.e., metallothioneins), which capture cisplatin before it reaches the DNA (Holford et al., 2000, Kelland, 2007, Kelley et al., 1988). This cellular response also seems to aid in mitigating oxidative stress, a frequently observed side effect of cisplatin treatment (Santos et al., 2007).

Recent studies from our lab revealed that upon cisplatin treatment, cancer cells drastically upregulate and redistribute their levels of inorganic polyphosphate (polyP) (Xie et al., 2019). PolyP is a polymer of up to 1000 inorganic phosphate (Pi) molecules, linked by high-energy phospho-anhydride bonds (reviewed in (Xie \& Jakob, 2019)). In bacteria, polyP protects against a variety of different stress conditions (i.e., oxidative stress, heat stress), stimulates biofilm formation, and regulates virulence (Rao et al., 2009) (Gray et al., 2014). Some of these functions can be explained by the ability of polyP to work as a proteinstabilizing scaffold (Gray et al., 2014). As such, polyP protects soluble proteins against stress-induced aggregation while promoting the formation of functional amyloids, including those involved in biofilms (Cremers et al., 2016). Other potential functions that have been associated with polyP are based on its chemical features as a buffer or high-energy storage molecule (reviewed in (Gray \& Jakob, 2015)). 
To gain more insights into the working mechanism of cisplatin and the role that polyP might play in the cellular response to this drug, we compared the effects of cisplatin treatment on wild-type and polyPdeficient $E$. coli. Our studies demonstrated that cisplatin triggers a gene expression pattern in wild-type bacteria that is consistent with the inactivation of the repressor Fur, the master regulator of iron homeostasis (Seo et al., 2014). The resulting gene expression changes lead to an apparent increase in iron uptake, whose deleterious effect is effectively mitigated by endogenous polyP. Deletion of the polyP synthesizing machinery causes a dramatic increase in cisplatin-induced mutagenesis rate and cell death. Both phenotypes are fully prevented in polyP-depleted bacteria by overexpressing iron storage proteins or by globally reducing the number of iron-containing proteins. Subsequent in vivo and in vitro studies revealed that polyP acts as a hitherto unknown iron-storage molecule under both stress and non-stress conditions, and, by chelating labile iron, acts as a physiologically relevant Fenton inhibitor.

\section{Result}

\section{PolyP protects $E$. coli against cisplatin toxicity}

Despite its prevalent use in anti-tumor treatment and its known broad antibacterial activity, the exact mechanism by which cisplatin kills cells is still not fully understood. To obtain more detailed insight into the cellular effects of cisplatin, we investigated the responses to and defenses against cisplatin toxicity in bacteria. Based on our recent discovery that polyP serves as an active defense mechanism against oxidative protein damage in bacteria (Gray et al., 2014), we compared the cisplatin-sensitivity of wildtype E. coli with mutant strains that lack either the polyP-synthesizing polyP kinase PPK (polyP-deplete) or the polyP-hydrolyzing enzyme exopolyphosphatase PPX (polyP-replete). We grew all three strains to mid-log phase in minimal MOPS glucose (MOPS-G) medium and exposed them to increasing amounts of cisplatin either on plates (Figure 1A) or in liquid culture (Figure S1A). Whereas E. coli wild-type or the $p p x$ deletion mutant strain did not show any growth defects when incubated on plates supplemented with $4 \mu \mathrm{g} / \mathrm{ml}$ of cisplatin, the $p p k$ deletion mutant, which lacks detectable polyP levels (Gray et al., 2014), showed a reproducible three to four log reduction in cell survival (Figure 1A). We obtained very similar 
results when we conducted the experiments in liquid culture. After a $20 \mathrm{~h}$ treatment with $10 \mu \mathrm{g} / \mathrm{ml}$ cisplatin in liquid media, wild-type E. coli showed an about 3-log decrease in survival while the ppk deletion strain showed a greater than 6-log decrease (Figure S1A).

Analysis of the endogenous polyP levels in wild-type $E$. coli did not reveal any significant upregulation of polyP in response to cisplatin treatment (Figure S1B), suggesting that the steady-state levels of polyP that are present in stationary phase E. coli (Rao \& Kornberg, 1996) are sufficient to confer the observed protection. To ascertain, however, that polyP synthesis is indeed required for the observed cisplatin resistance in wild-type $E$. coli, we transformed the $p p k$ deletion strain with plasmids encoding for either the native PPK protein or the previously characterized, catalytically inactive variant PPK-H435A (Kumble et al., 1996). As shown in Figure 1B, the expression of wild-type PPK fully rescued the cisplatin-sensitivity of the $p p k$ deletion strain. The expression of the catalytically inactive PPK variant, on the other hand, failed to rescue the growth defect. These results strongly suggested that endogenous levels of polyP are necessary and sufficient to protect $E$. coli against chronic cisplatin stress.

\section{PolyP protects $E$. coli against cisplatin-induced DNA damage}

To begin to understand how polyP protects bacteria against cisplatin toxicity, we analyzed the expression of select heat shock and SOS-response genes in cisplatin-treated wild-type, $p p k$ and $p p x$ deletion mutants. This line of experiments was instigated by our previous study, which showed that during severe oxidative stress, polyP-deficient bacteria upregulate their heat shock gene expression levels in an apparent attempt to compensate for the lack of polyP's chaperone function (Gray et al., 2014). Analysis of the mRNA levels of IbpA and DnaK, two genes whose expression levels are highly responsive towards protein unfolding stress in E. coli (Guisbert et al., 2008), did not reveal any significant change upon cisplatin treatment in any of the three tested strains (Figure S1C). In contrast, however, we found that the mRNA levels of the gene encoding for the cell division inhibitor SulA, a major component of the SOS response and an inducer of bacterial filamentation, significantly increased upon cisplatin treatment in the wild-type E. coli and $p p x$ deletion strain, and went up even more in bacteria lacking polyP. These results agreed 
with the original observation that cisplatin treatment triggers bacterial filamentation (Rosenberg et al., 1965), and indicated that at the concentrations used, cisplatin works as a DNA rather than a proteindamaging reagent in bacteria.

To assess the levels of DNA damage that cisplatin elicits in the ppk deletion strain versus in bacteria that contain measurable levels of polyP, we determined the mutagenesis rates before and after cisplatintreatment by counting the number of bacteria that gain the ability to grow on rifampicin plates (Touati et al., 1995). Rifampicin resistant mutations in the RNA polymerase gene $r p o B$ arise from single base substitutions, which prevent rifampicin from binding to and hence inhibiting RNA polymerase (Campbell et al., 2001). Under non-stress condition, the spontaneous rate of mutagenesis in all three tested strains was similarly low ( $<10$ mutants per $10^{8}$ cells) (Fig. 1C). Not unexpectedly given cisplatin's mode of action, this number drastically increased upon cisplatin treatment. However, the mutagenesis rate of the $p p k$ deletion was almost 3-fold higher compared to the mutagenesis rates of cisplatin-treated wild-type $E$. coli or the ppx deletion strain. Expression of a highly active PPK variant PPK-D230N, which substantially increases the steady state levels of polyP in vivo (Rudat et al., 2018), reduced the mutagenesis rate of the $p p k$ deletion strain to levels that were even lower than the ones observed in cisplatin-treated wild-type E. coli (Fig. 1C). These results suggested a previously unrecognized function of polyP in bacterial DNA damage control.

\section{Cisplatin triggers extensive transcriptional changes in wild-type and polyP-depleted E. coli}

We conducted RNAseq analysis to compare the transcriptional profile of wild-type and $\Delta p p k$ cells in response to a sub-lethal dose of cisplatin (i.e., $20 \mu \mathrm{g} / \mathrm{ml}$ cisplatin for 15 minutes). Compared to the respective untreated controls, we identified more than 1,100 differentially expressed genes (DEGs) in each strain (see supplemental Tables S1-S4). We categorized the DEGs into clusters of ontology according to their functional annotation (GOterm) (Ashburner et al., 2000), and focused our primary analysis on the two following groups: 1) DEGs in wild-type E. coli upon cisplatin treatment (Figure 2A; Tables S1, S4) since we reasoned that those genes will likely reveal the cellular effects that cisplatin 
exerts in bacteria; and 2) DEGs in cisplatin-treated wild-type versus $4 p p k$ strain (Figure 2B; Tables S3, S4) since we deduced that those genes will likely provide mechanistic insights into how polyP protects bacteria against cisplatin stress. The most upregulated genes in cisplatin-treated wild-type $E$. coli compared to the untreated control belonged to members of the SOS response (Figure 2A, Table S1). This was not an unexpected result since the SOS response is the canonical response to DNA damage. It controls more than 40 genes involved in transcriptional regulation, DNA repair mechanism, cell cycle arrest, and error-prone DNA synthesis (Courcelle et al., 2001, Friedberg, 1985, Friedberg et al., 1995) (Figure 2A). Many of the next most significantly altered cluster of DEGs in cisplatin-treated wild-type $E$. coli included genes involved in iron-sulfur cluster assembly, iron uptake, enterobactin synthesis and iron regulation (Fig. 2A, red bars). These results suggested that cisplatin treatment causes a disturbance in the cellular iron homeostasis. Indeed, when we compared the DEGs in cisplatin-treated wild-type with the DEGs identified under iron starvation or repletion conditions (Seo et al., 2014), we observed a statistically highly significant overlap (Fig. 2C). Particularly striking was the overlap between genes differentially regulated by cisplatin and genes previously reported to be directly controlled by the master transcriptional repressor Ferric Uptake Regulator FUR (Seo et al., 2014) (Figure 2C). In fact, the expression pattern in cisplatin-treated wild-type bacteria strongly resembled the expression pattern in E. coli mutants lacking functional FUR, i.e., the up-regulation of genes involved in iron uptake and the selective down-regulation of genes involved in iron utilization (Figure 2D). These results suggested that cisplatin treatment affects iron homeostasis in wild-type bacteria, either by triggering or signaling an iron starvation response. Other significantly enriched gene clusters in cisplatin-treated wild type bacteria included genes involved in fermentation and anaerobic ETC, as well as nitrate assimilation, sulfur and phosphate metabolism (Figure 2A).

\section{Cisplatin elicits iron stress in polyP-deficient $E$. coli}

Direct comparison of the DEGs in cisplatin-treated wild-type E. coli and polyP-deficient mutant cells revealed numerous gene clusters that responded similarly to cisplatin treatment in both strains (compare 
Fig. 2A with Fig. S2A; Table S3). In stark contrast, however, we found dramatic differences between the two strains in the expression of genes involved in amino acid transport, translation, transposition, and, particularly, iron homeostasis (Fig. 2B). Given the close connection between iron, oxidative stress, and DNA damage, we subsequently focused on the DEGs associated with iron homeostasis. We observed that polyP-depleted cells respond to cisplatin treatment with a much less pronounced expression of iron uptake genes and an even more pronounced downregulation of iron utilization genes (Figure 2D, Table S3). This expression pattern suggested that polyP-depleted bacteria experience a relative increase in the intracellular labile iron pool upon cisplatin treatment, which would explain their relative decrease in survival and increase in mutagenesis rate compared to wild-type bacteria (Fig. 1A, C). Given the polyanionic structure of polyP, and its previously shown ability to interact with divalent metals, such as $\mathrm{Ca}^{2+}, \mathrm{Mg}^{2+}$ and certain heavy metals (Keasling, 1997, Ruiz et al., 2011), we therefore considered the possibility that polyP serves as a hitherto unknown iron chelator. PolyP might complex excess iron as it is being taken up from the extracellular space and/or released from iron-containing proteins during cisplatin treatment. We reasoned that if this model were to be correct, we should be able to specifically rescue the cisplatin-sensitivity of the $p p k$ deletion strain by reducing the intracellular iron load during cisplatin treatment. To test this idea, we devised three different strategies; i) decreasing the extracellular iron concentration, which should reduce the amount of Fe-uptake during cisplatin stress (Braun, 2001); ii) overexpressing the iron storage protein FtnA, which should compensate for the lack of polyP; or iii) overexpressing the small RNA $r y h B$, which promotes the degradation of numerous mRNAs coding for iron-containing proteins, and hence reduces the number of iron-containing proteins in the cell (Massé \& Gottesman, 2002). For our first strategy, we grew wild-type and $p p k$ deletion strains in liquid medium supplemented with either normal $(+\mathrm{Fe})$ or low $(-\mathrm{Fe})$ concentrations, exposed them to our previously established cisplatin treatment, and determined cell survival and mutagenesis rates. The result that we obtained was fully consistent with our hypothesis; lowering the iron concentration in the media dramatically increased the survival and reduced the mutagenesis rates of the $p p k$ deletion strain to levels directly comparable to cisplatin-treated E. coli wild-type (Figure 3A, B). In contrast, cisplatin treatment 
under low versus normal iron conditions did not yield any noticeable difference in the cisplatin resistance of wild-type E. coli. These results suggested that iron taken up from the media in response to cisplatin treatment was successfully complexed or otherwise neutralized by polyP. We obtained a very similar result upon overexpression of the plasmid-encoded iron storage protein FtnA, which significantly improved survival and reduced the mutagenesis rates in the cisplatin-treated $p p k$ deletion strain but not in wild-type E. coli (Fig. 3C, D). These results demonstrated that expression of a protein-based iron chelator fully compensates for the lack of polyP. We finally tested the effect of $r y h B$ overexpression, a strategy that bacteria typically use to reduce the number of Fe-containing proteins under low-iron conditions (Massé \& Gottesman, 2002). Indeed, and in agreement with our previous results, we found that the overexpression of $r h y B$ restored the cisplatin resistance of polyP-depleted cells to wild-type like levels while rendering the resistance of wild-type E. coli unaltered (Figure 3E, F). These results suggested that iron complexed in metalloproteins might contribute to the iron toxicity in the absence of polyP. Since previous reports documented that cisplatin covalently binds cysteine residues in proteins (Ishikawa \& AliOsman, 1993, Kelland, 2007, Williams et al., 2004), including those involved in iron binding (Bischin et al., 2011), we finally tested the idea that cisplatin targets iron-containing proteins in bacterial cell lysates. We therefore prepared wild-type or $\triangle p p k$ crude extracts, and measured the activity of aconitase, an enzyme, whose iron-sulfur cluster is coordinated via three oxidation-sensitive cysteines. We found that increasing concentrations of cisplatin indeed increasingly reduced the activity of aconitase at similar level in both wild-type and $\Delta p p k$ extracts (Figure S3). Together, these results suggested that endogenous polyP provides an effective non-proteinogenic mechanism to protect bacteria against cisplatin-mediated accumulation of free iron and Fe-mediated oxidative damage.

\section{PolyP acts as a physiologically relevant iron-storage molecule in vivo}

Iron homeostasis is a tightly regulated mechanism, necessitated by the fact that unbound labile iron is highly toxic under aerobic growth conditions. This toxicity appears to be primarily caused by the ability of free iron to interact with peroxide (i.e., Fenton reaction), which leads to the production of highly 
reactive hydroxyl radicals (Dixon \& Stockwell, 2014). To further evaluate the idea that polyP serves as a general, hitherto unrecognized iron storage molecule in bacteria, we turned to a mutant strain of E. coli, which lacks the master iron repressor Fur. Deletion of Fur triggers an iron starvation response, which, similar to the situation we observed in cisplatin-treated wild-type E.coli, leads to gene expression changes that are geared towards replenishing the intracellular iron pool (Andrews et al., 2003, Massé \& Gottesman, 2002). As a cellular consequence, fur deletion strains suffer from an intracellular iron overload, which causes severe growth defects and significantly higher mutagenesis rates under aerobic but not under anaerobic growth conditions (Touati et al., 1995). To test whether polyP functions as an iron storage molecule in a $\Delta f u r$ deletion strain, we generated $\Delta f u r \Delta p p k$ double deletion strains, and analyzed growth and mutagenesis rates under both aerobic and anaerobic growth conditions. As shown in Figures $4 \mathrm{~A}-\mathrm{C}$, additional deletion of $p p k$ in the $\Delta f u r$ deletion strain significantly aggravated the growth defect and increased the mutagenesis rate specifically under aerobic growth conditions (Fig. 4A-C). These results were fully consistent with our prior observations and supported our conclusion that polyP protects bacteria generally against conditions of Fe-overload. To finally test whether polyP also serves as an iron reservoir under non-stress conditions, we cultivated E. coli wild type, $\Delta p p k$ and $\Delta p p x$ strains in M9 minimal medium in the presence of increasing concentrations of the iron chelator 2,2'-dipyridyl, using gluconate as sole carbon source. By offering solely gluconate, bacterial growth depends on the activity of the iron-sulfur cluster protein gluconate dehydratase, and hence on the availability of intracellular iron (Gardner \& Fridovich, 1991). Addition of 2,2'-dipyridyl to the growth media reduces the intracellular iron pools and, at sufficiently high levels, prevents bacterial growth as it depletes the Fe-S cluster in gluconate dehydratase. As shown in Fig. 4D (and Fig. S4A, B), whereas the $\triangle p p x$ strain was slightly more resistant towards the presence of the chelator compared to wild-type E. coli, the $\triangle p p k$ strain was significantly more sensitive. Less than $100 \mu \mathrm{M}$ 2,2'-dipyridyl in the growth media was sufficient to decrease the relative growth rate of the $\Delta p p k$ strain by $50 \%$ while more than $150 \mu \mathrm{M}$ of the chelator was necessary to trigger the same growth defect in wild-type E. coli (Fig. 4D, Figs. S4A, B). These results demonstrated that lack of endogenous polyP drastically increases the sensitivity of $E$. coli towards the 
presence of iron chelators in the media and supports the conclusion that polyP serves as a physiologically relevant iron storage molecule in E. coli.

\section{PolyP protects against Fe-mediated DNA damage in vitro}

To directly test whether polyP, through complexing iron, mitigates the Fenton reaction, we monitored the $\mathrm{H}_{2} \mathrm{O}_{2} / \mathrm{FeSO}_{4}$-mediated oxidation of 2,2'-azino-bis(3-ethylbenzothiazoline-6-sulphonic acid) (ABTS)

(Zheng \& Huang, 2014) in the presence of increasing amounts of polyP (Fig. 5A). ABTS, once oxidized by $\mathrm{H}_{2} \mathrm{O}_{2} / \mathrm{FeSO}_{4}$-produced hydroxyl radicals, shows a strong absorbance signal at $414 \mathrm{~nm}$. As shown in Fig. 5A, the presence of polyP prevented ABTS oxidation in a concentration-dependent manner, indicating that chelation of $\mathrm{Fe}^{2+}$ by polyP inhibits the Fenton reaction. In fact, $20 \mu \mathrm{M}$ poly $\mathrm{P}_{300}$ (in $\mathrm{P}_{\mathrm{i}}$ units) was sufficient to prevent oxidation of ABTS by a mixture of $5 \mu \mathrm{M} \mathrm{FeSO}_{4}$ and $20 \mu \mathrm{M} \mathrm{H}_{2} \mathrm{O}_{2}$ (Fig. 5A). To test whether the association of $\mathrm{Fe}^{2+}$ with polyP also protects DNA against Fe-mediated oxidative damage, we incubated $10 \mu \mathrm{M}$ of linearized DNA with a mixture of $50 \mu \mathrm{M} \mathrm{Fe}^{2+} / 5 \mathrm{mM} \mathrm{H}_{2} \mathrm{O}_{2}$ in the absence and presence of polyP $\mathrm{P}_{300}$ (Fig. 5B). Whereas in the absence of polyP, all of the DNA was oxidatively degraded within a $30 \mathrm{~min}$ incubation period, the presence of $5 \mathrm{mM}$ poly $\mathrm{P}_{300}$ (in Pi-units), almost completely prevented the degradation of DNA. Presence of inorganic phosphate (Pi) in the form of either sodium- or potassium phosphate did not have any protective effect even when used at concentrations as high as $75 \mathrm{mM}$ (Fig. 5B), confirming that the polyanionic nature of the polyP chain is necessary to sequester iron in a non-reactive state. In summary, these results demonstrate that polyP acts as a physiologically relevant iron storage molecule, capable of preventing the production of hydroxyl radical by the Fenton reaction.

\section{Discussion}

Iron serves as an essential co-factor in many enzymes, which are involved in processes ranging from metabolism to DNA synthesis and cell division. Yet, free iron is highly toxic under oxygen richcondition as it readily undergoes the Fenton or Haber-Weiss reactions, thereby producing extremely 
reactive oxygen species, particularly hydroxyl radicals (Dixon \& Stockwell, 2014) (Fig. 6A). Because of this dichotomy in cellular need for and risk of free iron, aerobically growing organisms such as $E$. coli tightly regulate their iron homeostasis. Here we demonstrate that cisplatin, an anti-cancer drug and broadspectrum antimicrobial, triggers cytotoxicity in bacteria not only through its ability to crosslink DNA but also by causing cellular iron overload. By using a combination of genetic and biochemical tools, we discovered that bacteria defend themselves against this secondary insult through polyP, which effectively complexes the iron, prevents the Fenton reaction and mitigates cisplatin toxicity (Fig. 6B).

It is well established that polyP interacts with metals such as $\mathrm{Ca}^{2+}$ to form acidocalcisomes and protects organisms by complexing and sequestrating heavy metals (Docampo et al., 2005, Tocheva et al., 2013, Toso et al., 2011). In contrast, however, very little is known about the interaction of polyP with iron, the physiological relevance of such an interaction, or its potential role in the Fenton reaction (Rachmilovich-Calis et al., 2011, Richter \& Fischer, 2006). A much-needed search for physiologically relevant Fenton inhibitors revealed that nucleotide phosphates, such as ATP, either stimulate or prevent the Fenton reaction, depending on the number of iron coordination sites that were occupied by phosphates in the complex (Richter \& Fischer, 2006). The most effective Fenton inhibitor turned out to be dimers of ATP-y-S, which, through their six existing phosphate groups, block all iron coordination sites. This appears to prevent $\mathrm{H}_{2} \mathrm{O}_{2}$ from reacting with iron and mitigates hydroxyl radical formation. We now propose that polyP, due to its polyanionic nature and structural flexibility, is able to also occupy all relevant coordination sites in iron, thereby interfering with peroxide binding and preventing the Fenton reaction (Fig. 6B).

Our studies revealed noteworthy parallels between the protective function of polyP in bacteria exposed to cisplatin and in bacteria that lack the iron repressor Fur. Our transcriptional analysis of cisplatin-treated wild-type bacteria supported this conclusion by demonstrating that close to $80 \%$ of previously identified Fur-regulons are upregulated in bacteria treated with cisplatin (Seo et al., 2014). At first glance, these results suggested that bacteria treated with cisplatin suffer from stress conditions that trigger intracellular iron depletion; hence, the upregulation of siderophores and transport mechanisms 
aimed to replenish the intracellular iron pools. However, analysis of the cisplatin response in polyPdepleted bacteria yielded quite the opposite result, and, in fact, suggested that cisplatin triggers an accumulation of free iron, which becomes highly toxic and mutagenic unless chelated by polyP. Further support for this conclusion came from cisplatin-treatment studies in Fe-deplete media, as well as complementation studies in which we either overexpressed the E. coli Fe-storage protein FtnA, or rhyB, a small RNA that down-regulates the amount of Fe-S cluster proteins in bacteria. In all three scenarios, cisplatin-treatment of the ppk deletion strain no longer increased the mutagenesis rate or affected survival beyond what we observed in cisplatin-treated wild-type E. coli. These results strongly argue that cisplatin treatment causes an increase in intracellular iron, which, unless chelated by polyP, significantly increases the toxicity of cisplatin. Since cisplatin is well known for its ability to interact with and bind to cysteine and methionine residues in proteins (Peleg-Shulman et al., 2002), and Fur contains a redox sensitive cysteine-coordinating zinc site (d'Autréaux et al., 2007), we now speculate that Fur itself might become a target of cisplatin. Inactivation of Fur would misleadingly send an iron starvation signal to the cell, causing iron accumulation. Intriguingly, very recent studies showed similarly disruptive effects of cisplatin on the iron homeostasis in cancer cells (Miyazawa et al., 2019). In contrast to bacteria, however, which ultimately suffer from iron overload, cisplatin-treated cancer cells experience true iron starvation. This iron starvation phenotype is triggered by the covalent modification of two cysteines in the iron regulatory protein 2 (IRP2), a central activator of the mammalian iron starvation response (Miyazawa et al., 2019). Once inhibited, IRP2 is unable to downregulate the iron chelator ferritin, causing persistent iron depletion. Our realization that polyP serves as iron chelator helps to explain our recent finding that endogenous levels of polyP positively correlate with apoptosis in cisplatin-treated cancer cells (Xie et al., 2019). We now reason that by chelating iron, polyP further potentiates the iron starvation phenotype in cancer cells, hence causing the observed increase in cytotoxicity (Miyazawa et al., 2019, Xie et al., 2019). The ability of polyP to complex iron might also contribute to its protective function under oxidative stress conditions, as well as other cellular insults that cause protein-bound iron to be released. Chelation of iron by polyP will not only prevent secondary oxidative stress conditions but would allow 
iron to be rapidly re-incorporated into proteins without the activation of complex and energy-consuming uptake systems once the stress is removed. It remains to be tested whether and how association of polyP with iron affects some of the other known functions of polyP, such as its ability to interact with and stabilize unfolding proteins, or its activity in blood coagulation and inflammation (Morrissey et al., 2012), adding a potentially new layer of complexity to this structurally simple molecule.

\section{Material and Methods}

Bacterial Strains and Growth Conditions. All strains, plasmids, and oligonucleotides used in this study are listed in Tables S5-S7, respectively. Gene deletions were generated by $\lambda$ red-mediated site-specific recombination (Datsenko \& Wanner, 2000). All chromosomal mutations were confirmed by PCR. E. coli MG1655 was grown at $37^{\circ} \mathrm{C}$ in lysogenic broth (LB; Fisher) or MOPS minimal medium (Teknova) containing $0.2 \% \mathrm{w} / \mathrm{v}$ glucose and $1.32 \mathrm{mM} \mathrm{K}_{2} \mathrm{HPO}_{4}$ (MOPS-G). To conduct cisplatin resistance tests on plates, M9 minimal medium (Sambrook et al., 1989) containing 0.2\% glucose (M9-G) was supplemented with $1.5 \%$ agar. When indicated, $0.2 \% \mathrm{w} / \mathrm{v}$ gluconate was used instead of glucose (M9-gluconate). For iron-depleted conditions, M9-G medium was mixed and incubated with $2 \mathrm{~g} / 1$ Chelex100 (BioRad) for $1 \mathrm{hr}$ at room temperature under constant agitation. The chelated solution was then sterile-filtered. For pBAD expression induction, arabinose $(0.2 \% \mathrm{w} / \mathrm{v})$ was added 15 minutes prior to the experiment in case of liquid assays or added to the media in case of plate assays. The following antibiotics were added when appropriate: Chloramphenicol $(30 \mu \mathrm{g} / \mathrm{ml})$, rifampicin $(200 \mu \mathrm{g} / \mathrm{ml})$, kanamycin $(50 \mu \mathrm{g} / \mathrm{ml})$, or ampicillin $(100 \mu \mathrm{g} / \mathrm{ml})$.

Growth under iron starvation. Iron starvation growth assays were performed as described in (Outten et al., 2004). Briefly, E. coli MG1655 wild-type, ppk and ppx deletion strains were grown overnight in M9gluconate medium, diluted and cultivated at $37^{\circ} \mathrm{C}$ until $\mathrm{OD}_{600}$ of 0.5 was reached. Cells were then diluted 1:100 into M9-gluconate medium supplemented with the indicated concentrations of 2,2' bipyridyl (stock dissolved in 100 mM DMSO; Sigma-Aldrich). Each condition was performed in triplicate and growth 
was monitored for $18 \mathrm{~h}$. The $\mathrm{OD}_{600}$ reached after $18 \mathrm{~h}$ was then normalized to the corresponding growth rate in M9-gluconate in the absence of chelator and plotted.

Cisplatin survival assay. E. coli MG1655 wild-type and the isogenic mutant strains were grown at $37^{\circ} \mathrm{C}$ with shaking in MOPS-G medium to an $\mathrm{OD}_{600} \sim 0.4-0.8$ and harvested by centrifugation. To analyze cisplatin sensitivity in liquid culture, the cells were resuspended in MOPS-G medium to an OD $_{600}$ of 0.4 , supplemented with various concentrations of cisplatin (stock solution $0.9 \mathrm{mg} / \mathrm{ml}$ in sterile ${ }_{\mathrm{dd}} \mathrm{H} 2 \mathrm{O}$; SigmaAldrich) and incubated at $37^{\circ} \mathrm{C}$ with shaking $(200 \mathrm{rpm})$. At defined time points of incubation $(1 \mathrm{~h}-20 \mathrm{~h})$, the cells were harvested by centrifugation, washed twice, 10-fold serially diluted and plated onto LB agar. Survival was assessed after overnight incubation at $37^{\circ} \mathrm{C}$. To determine the survival of bacteria when grown on cisplatin-containing plates, bacteria were cultivated in MOPS-G media until $\mathrm{OD}_{600}$ of 0.5 was reached. Then, the bacteria were 10-fold serially diluted and plated onto M9-G plates containing various concentrations of cisplatin. Colonies were counted after a $24 \mathrm{~h}$ incubation at $37^{\circ} \mathrm{C}$. To compare the cisplatin sensitivity of bacteria in iron-deplete liquid media, the bacteria were first grown in MOPS-G media as described above. Once an $\mathrm{OD}_{600}$ of 0.4 was reached, the bacteria were centrifuged, washed and resuspended in either untreated M9-G $(+\mathrm{Fe})$ media or chelexed M9-G $(-\mathrm{Fe})$ media in the absence or presence of $10 \mu \mathrm{g} / \mathrm{ml}$ of cisplatin. At defined time points of incubation $(1 \mathrm{~h}-20 \mathrm{~h})$, the cells were harvested by centrifugation, washed twice, 10-fold serially diluted and plated onto LB agar.

Mutagenesis assay. Mutagenesis rates were measured as described (Krisko \& Radman, 2013). Briefly, cells were grown overnight in MOPS-G medium, diluted 1:100 into $30 \mathrm{ml}$ fresh MOPS-G medium and cultivated at $37^{\circ} \mathrm{C}$ until $\mathrm{OD}_{600}$ of 0.5 was reached. The bacterial suspension was either left untreated or supplemented with $10 \mu \mathrm{g} / \mathrm{ml}$ cisplatin, and further incubated for $1 \mathrm{hr}$. After the incubation, untreated and treated bacteria were washed twice in MOPS-G media and resuspended in $5 \mathrm{ml}$ of LB media. The bacteria were then incubated overnight at $37^{\circ} \mathrm{C}$ with shaking. Serial dilutions were made and plated onto both LB agar and LB-rifampicin agar plates. After $24 \mathrm{~h}$ of incubation at $37^{\circ} \mathrm{C}$, the colony forming units (CFU) were scored. The mutation frequency was calculated by dividing the number of rifampicin-positive colonies by the total number of colonies. 
RNAseq analysis. Four biological replicates of wild-type E. coli MG1655 and $\triangle p p k$ were cultivated in MOPS-G medium at $37^{\circ} \mathrm{C}$ until $\mathrm{OD}_{600}$ of $0.4-0.5$ was reached. Cells $(1 \mathrm{ml})$ were harvested either before or $15 \mathrm{~min}$ after the treatment with $20 \mu \mathrm{g} / \mathrm{ml}$ cisplatin in $1 \mathrm{ml}$ of ice-cold methanol $\left(-80^{\circ} \mathrm{C}\right)$ to stop transcription. After centrifugation and removal of the supernatant, total RNA was prepared using the Ambion RiboPure-Bacteria Kit (Thermo Fisher Scientific) according to the manufacturer's instructions. The samples were DNase I treated, followed by depletion of rRNA using the Illumina Ribo Zero Kit (Illumina) for Gram-negative bacteria. Fifty base single end sequencing was performed on an Illumina HiSeq 4000 using the University of Michigan DNA Sequencing Core. Sequence reads from the RNA-seq were mapped onto the reference genome (NC_000913). Genes with a log2 fold change $>0.5$ and an FDR value $<0.01$ were considered as differentially expressed genes (DEGs).

GOC enrichment and analysis. Differentially regulated genes upon cisplatin treatment and/or between strains were categorized according to their annotated COG categories (Ashburner et al., 2000). Functional enrichment of COG categories was determined by performing a modified one-tailed Fisher's Exact test (EASE score from DAVID ), with a $p$-value $<0.05$ considered significant. Comparison to iron-regulated genes (Seo et al., 2014) seen in Venn Diagram in Fig. 2C, was performed using a Fisher's Exact test. The heatmap was produced using open-source statistical software R (https://www.r-project.org/) with $\log 2$ fold change data. Figures 2 and S2 were also produced in R.

Enzymatic assays. The aconitase activity assay was performed according to the manufacturer's protocol (MAK051, Sigma Aldrich). Briefly, bacterial cell pellets were resuspended in $1 \mathrm{ml}$ of aconitase lysis buffer (0.1 mM Tris-HCl, pH 8.0, 0.1 M KCl, $1 \mathrm{mM} \mathrm{PMSF}$, and 0.6 $\mu \mathrm{g} / \mathrm{ul}$ lysozyme) and lysed by 5-6 rounds of freeze $\&$ thaw cycles. The lysates were centrifuged at $14,000 \mathrm{rpm}$ for $10 \mathrm{~min}$ at $4^{\circ} \mathrm{C}$. The total protein concentration was determined using the Bradford assay. The aconitase assay was performed by mixing $100 \mu \mathrm{g}$ of cell lysate with $200 \mu \mathrm{l}$ of $1 \mathrm{x}$ aconitase assay buffer $\left(0.6 \mathrm{mM} \mathrm{MnCl}_{2}, 25 \mathrm{mM}\right.$ sodium citrate, $0.25 \mathrm{~mm}$ ADP, $50 \mathrm{mM}$ Tris- $\mathrm{HCl}, \mathrm{pH}$ 7.6). The absorbance was recorded at $340 \mathrm{~nm}$, and the specific aconitase activity was calculated per milligram of total proteins (Kaur et al., 2017). 
In vitro Fenton reaction and DNA damage assay - The ABTS assay was performed as previously described in (Zheng \& Huang, 2014). In brief, $250 \mu \mathrm{M}$ ABTS was mixed with $5 \mu \mathrm{M} \mathrm{FeSO}_{4}$ and $200 \mu \mathrm{M}$ $\mathrm{H}_{2} \mathrm{O}_{2}$ in the absence or presence of increasing concentrations of poly $\mathrm{P}^{300}$ (see figure legends for details). The assay was performed in $10 \mathrm{mM}$ acetate buffer, $\mathrm{pH} 3.6$ to control acidity. After 30 min of incubation at $37^{\circ} \mathrm{C}$, the mixture was read at an absorbance of $414 \mathrm{~nm}$. The DNA damage assay was performed by mixing $50 \mu \mathrm{M} \mathrm{FeSO}_{4}, 5 \mathrm{mM} \mathrm{H}_{2} \mathrm{O}_{2}$ and $10 \mu \mathrm{M}$ linearized DNA from the plasmid pBAD18 in water with the indicated concentration of either $\mathrm{Na}_{2} \mathrm{HPO}_{4}, \mathrm{KH}_{2} \mathrm{PO}_{4}$, or polyP $\mathrm{P}_{300}$ (concentration given in $\mathrm{P}_{\mathrm{i}}$-units). The reaction was initiated by the addition of $\mathrm{H}_{2} \mathrm{O}_{2}$ and incubated for $30 \mathrm{~min}$ at $37^{\circ} \mathrm{C}$. Then, samples were loaded onto an agarose gel. Staining with ethidium bromide was used to visualize the DNA bands.

\section{Acknowledgements}

We thank the DNA Sequencing Core (BRCF), the Bioinformatics Core of University of Michigan and Christopher Sifuentes for RNA sequencing and data analysis. We thank Jan Dahl, Michael Gray and the entire Jakob lab for helpful discussions and important input. This work was supported by NIH grants GM122506 to U.J., a NIH T32 Career Training in the Biology of Aging grant to E.Q.; F.B. was funded by an EMBO long-term fellowship (ALTF 601-2016). 


\section{Figure legends}

\section{Figure 1. PolyP confers cisplatin resistance in $E$. coli}

A. Logarithmically growing E. coli MG1655 wild-type (wt), $4 p p k$ or $\Delta p p x$ were 10-fold serially diluted, spotted onto M9-G plates containing $4 \mu \mathrm{g} / \mathrm{ml}$ cisplatin and incubated at $37^{\circ} \mathrm{C}$ overnight. B.

Logarithmically growing E. coli wild-type containing the empty vector pBAD18b, or the $p p k$ mutant strain containing either the empty vector or expressing wild-type PPK or the enzymatically inactive $\mathrm{PPK}_{\mathrm{H} 435 \mathrm{~A}}$ mutant were 10 -fold serially diluted, spotted onto plates containing $0.02 \% \mathrm{w} / \mathrm{v}$ arabinose and 4 $\mu \mathrm{g} / \mathrm{ml}$ cisplatin, and incubated at $37^{\circ} \mathrm{C}$ overnight. Experiments shown in A, B were conducted at least 4 times, and a representative result is shown. C. The mutagenesis rates of logarithmically growing wildtype (wt), $\triangle p p x, \triangle p p K$ or $\Delta p p k$ expressing the highly active PPK-D230N mutant protein before and $1 \mathrm{~h}$ after treatment with $10 \mu \mathrm{g} / \mathrm{ml}$ cisplatin in liquid culture was determined by counting the number of colonies able to grow on rifampicin plates ( $\mathrm{n}=3$; *, $\mathrm{P}<0.05$; ****, $\mathrm{P}<0.0001$; ns, non-significant, one-way ANOVA).

\section{Figure 2. Global gene expression changes in response to cisplatin treatment}

A. Functional classification (GOterm) of genes differentially expressed in wild-type E. coli upon 15 min treatment with a non-lethal cisplatin concentration $(20 \mu \mathrm{g} / \mathrm{ml})$ (Table S1, S4). Categories related to iron metabolism are highlighted in red. B. Functional classification (GOterm) of genes differentially expressed in $\triangle p p k$ and wild-type $E$. coli upon 15 min treatment with a non-lethal cisplatin concentration $(20 \mu \mathrm{g} / \mathrm{ml})$ (Table S3, S4). $P$-values are shown in white over each bar, from a modified Fisher's Exact test. C. Venn diagram of genes belonging to the fur regulon (green circle), genes differentially expressed in wild-type E. coli upon cisplatin treatment (cyan circle), and genes differentially expressed in a fur deletion strain under iron repletion and starvation conditions (Seo et al., 2014) (red circle). $P$-values and odds ratios from Fisher Exact Tests. D. Heatmap of Fur-regulated genes, which are differentially expressed in cisplatin 
treated wild-type (wt) and $\Delta p p k$ cells. Data are log2 fold change, range: -4 (blue) to 4 (red). Ratio of $p p k$ to wild-type is shown in the right column. Genes are organized according to their functional annotations.

Figure 3. Low-iron conditions reduce cisplatin toxicity in polyP deficient $E$. coli

A, B. Exponentially growing E. coli wild-type (wt) and $p p k$ deletion strains were exposed to $10 \mu \mathrm{g} / \mathrm{ml}$ cisplatin in untreated (+Fe) or chelexed (-Fe) M9-G media for (A) $20 \mathrm{~h}$ to determine survival or (B) for 1 $\mathrm{h}$ to determine the rate of mutagenesis. C, D. Exponentially growing E. coli wild-type and $p p k$ deletion strains carrying either an empty plasmid or a plasmid overexpressing the iron storage protein $f \operatorname{tn} A$ were exposed to $10 \mu \mathrm{g} / \mathrm{ml}$ cisplatin in M9-G media for either $20 \mathrm{~h}$ to determine survival (C) or for $1 \mathrm{~h}$ to determine the rate of mutagenesis (D). E, F. Exponentially growing wild-type and $\Delta p p k$ cells carrying an empty plasmid or a plasmid overexpressing $r y h B$ were serially diluted, spotted onto plates containing $0.02 \% \mathrm{w} / \mathrm{v}$ arabinose and $4 \mu \mathrm{g} / \mathrm{ml}$ cisplatin and incubated at $37^{\circ} \mathrm{C}$ to determine survival (E), or exposed to $10 \mu \mathrm{g} / \mathrm{ml}$ cisplatin in M9-G media for $1 \mathrm{~h}$ to determine the rate of mutagenesis $(\mathrm{F}) . \mathrm{n}=3 ; * * * *, \mathrm{P}<0.0001$; ns, non-significant; one-way ANOVA.

\section{Figure 4. Poly $P$ acts as an iron-storage molecule in vivo}

A, B. Growth of E. coli wild-type, $\Delta p p k$, $\Delta f u r$ and $\triangle f u r \Delta p p k$ strains in MOPS-G media under aerobic (A) or anaerobic condition (B) conditions. C. Mutagenesis rate of each strain under aerobic and anaerobic growth conditions. ( $\mathrm{n}=3 ; * * * *, \mathrm{P}<0.0001$; ns, non-significant; one-way ANOVA). D. Exponentially growing E. coli wild-type, $\triangle p p k$ and $\triangle p p x$ deletion strains were diluted into M9-Gluconate supplemented with increasing concentrations of the iron chelator 2,2' bipyridyl. The maximal growth achieved after $18 \mathrm{~h}$ incubation at $37^{\circ} \mathrm{C}$ was normalized against the growth in M9-Gluconate without chelator. Error bars are \pm one standard deviation for technical triplicates. Experiments were performed in triplicates (for biological replicates see Fig. S4A, B) and a representative result is shown. 


\section{Figure 5. PolyP inhibits Fenton reaction in vitro}

A. ABTS oxidation by $20 \mu \mathrm{M} \mathrm{H}_{2} \mathrm{O}_{2}$ and $5 \mu \mathrm{M} \mathrm{FeSO}_{4}$ was monitored at $414 \mathrm{~nm}$ in the absence or presence of $1,2,3,4,5,7.5,10,20$ or $30 \mu \mathrm{M}$ of polyP $\mathrm{P}_{300}$ (in Pi units). No significant oxidation was observed in the presence of $\mathrm{H}_{2} \mathrm{O}_{2}$ or $\mathrm{FeSO}_{4}$ alone (n=3). B. Oxidative degradation of 200 ng of DNA after 30 min incubation with $2 \mathrm{mM} \mathrm{H}_{2} \mathrm{O}_{2}$ and $50 \mu \mathrm{M} \mathrm{FeSO}_{4}$ in the absence or presence of 5, 10 or $25 \mathrm{mM}$ polyP 300 (in Pi-units), $75 \mathrm{mM} \mathrm{NaH} \mathrm{PO}_{4}$ or $75 \mathrm{mM} \mathrm{KH}_{2} \mathrm{PO}_{4}$. Samples were applied onto an agarose gel and visualized using ethidium bromide $(\mathrm{n}=3)$.

\section{Figure 6. Model for the protective effects of polyphosphate against cisplatin}

A. Our data suggest that cisplatin treatment causes iron accumulation that might contribute to a second mode of killing through Fenton-mediated oxidative stress and DNA damage. Iron stress likely results from a combination of events; the release of protein-bound iron, and the inactivation of the master repressor of bacterial iron homeostasis Fur that triggers gene expression changes aimed to increase the cellular iron load. Subsequently, cellular free iron levels increase and can wreak havoc under aerobic growth conditions by producing highly reactive oxygen species, such as hydroxyl radicals. B. Due to its polyanionic nature, endogenous polyP binds free iron, and prevents iron to act as a catalyst for the Fenton reaction, thereby drastically reducing the toxicity of cisplatin. 


\section{REFERENCES:}

Andrews SC, Robinson AK, Rodríguez-Quiñones F (2003) Bacterial iron homeostasis. FEMS microbiology reviews 27: 215-237

Ashburner M, Ball CA, Blake JA, Botstein D, Butler H, Cherry JM, Davis AP, Dolinski K, Dwight SS, Eppig JT (2000) Gene ontology: tool for the unification of biology. Nature genetics 25: 25-29

Bancroft DP, Lepre CA, Lippard SJ (1990) Platinum-195 NMR kinetic and mechanistic studies of cis-and trans-diamminedichloroplatinum (II) binding to DNA. Journal of the American Chemical Society 112: 6860-6871

Bischin C, Lupan A, Taciuc V, Silaghi-Dumitrescu R (2011) Interactions between proteins and platinum-containing anti-cancer drugs. Mini reviews in medicinal chemistry 11:214224

Braun V (2001) Iron uptake mechanisms and their regulation in pathogenic bacteria. International journal of medical microbiology 291: 67-79

Campbell EA, Korzheva N, Mustaev A, Murakami K, Nair S, Goldfarb A, Darst SA (2001) Structural mechanism for rifampicin inhibition of bacterial RNA polymerase. Cell 104: 901912

Courcelle J, Khodursky A, Peter B, Brown PO, Hanawalt PC (2001) Comparative gene expression profiles following UV exposure in wild-type and SOS-deficient Escherichia coli. Genetics 158: 41-64

Cremers CM, Knoefler D, Gates S, Martin N, Dahl J-U, Lempart J, Xie L, Chapman MR, Galvan V, Southworth DR (2016) Polyphosphate: a conserved modifier of amyloidogenic processes. Molecular cell 63: 768-780

d'Autréaux B, Pecqueur L, Gonzalez de Peredo A, Diederix RE, Caux-Thang C, Tabet L, Bersch B, Forest E, Michaud-Soret I (2007) Reversible redox-and zinc-dependent dimerization of the Escherichia coli fur protein. Biochemistry 46: 1329-1342

Datsenko KA, Wanner BL (2000) One-step inactivation of chromosomal genes in Escherichia coli K-12 using PCR products. Proceedings of the National Academy of Sciences 97: 6640-6645

Dixon SJ, Stockwell BR (2014) The role of iron and reactive oxygen species in cell death. Nature chemical biology 10: 9

Docampo R, de Souza W, Miranda K, Rohloff P, Moreno SN (2005) Acidocalcisomes?

Conserved from bacteria to man. Nature Reviews Microbiology 3: 251-261

Eastman A (1987) The formation, isolation and characterization of DNA adducts produced by anticancer platinum complexes. Pharmacology \& therapeutics 34: 155-166

Friedberg E (1985) DNA repair WH Freeman \& CO. New York

Friedberg E, Walker G, Siede W (1995) SOS responses and DNA damage tolerance in prokaryotes. DNA repair and mutagenesis: 407-464

Galanski M, Slaby S, Jakupec MA, Keppler BK (2005) Synthesis and in vitro antitumor potency of (cyclohexane-1,2-diamine)platinum(II) complexes with aminotris(methylenephosphonic acid) as bone-seeking ligand. Bioinorg Chem Appl: 179-90 Gardner PR, Fridovich I (1991) Superoxide sensitivity of the Escherichia coli 6phosphogluconate dehydratase. Journal of Biological Chemistry 266: 1478-1483 Gray MJ, Jakob U (2015) Oxidative stress protection by polyphosphate-new roles for an old player. Current opinion in microbiology 24: 1-6 
Gray MJ, Wholey W-Y, Wagner NO, Cremers CM, Mueller-Schickert A, Hock NT, Krieger AG, Smith EM, Bender RA, Bardwell JC (2014) Polyphosphate is a primordial chaperone.

Molecular cell 53: 689-699

Guisbert E, Yura T, Rhodius VA, Gross CA (2008) Convergence of molecular, modeling, and systems approaches for an understanding of the Escherichia coli heat shock response.

Microbiol Mol Biol Rev 72: 545-554

Hannon MJ (2007) Metal-based anticancer drugs: from a past anchored in platinum chemistry to a post-genomic future of diverse chemistry and biology. Pure and Applied Chemistry 79: 2243-2261

Holford J, Beale P, Boxall F, Sharp S, Kelland L (2000) Mechanisms of drug resistance to the platinum complex ZD0473 in ovarian cancer cell lines. European Journal of Cancer 36: 1984-1990

Ishikawa T, Ali-Osman F (1993) Glutathione-associated cis-diamminedichloroplatinum (II) metabolism and ATP-dependent efflux from leukemia cells. Molecular characterization of glutathione-platinum complex and its biological significance. Journal of Biological Chemistry 268: 20116-20125

Karasawa T, Sibrian-Vazquez M, Strongin RM, Steyger PS (2013) Identification of cisplatinbinding proteins using agarose conjugates of platinum compounds. PloS one 8

Kaur T, Blair D, Moschilla J, Stannard W, Zadnik M (2017) Teaching Einsteinian physics at schools: part 1, models and analogies for relativity. Physics Education 52: 065012

Keasling J (1997) Regulation of intracellular toxic metals and other cations by hydrolysis of polyphosphate. Annals of the New York Academy of Sciences 829: 242-249

Kelland L (2007) The resurgence of platinum-based cancer chemotherapy. Nature Reviews Cancer 7: 573-584

Kelley SL, Basu A, Teicher BA, Hacker MP, Hamer DH, Lazo JS (1988) Overexpression of metallothionein confers resistance to anticancer drugs. Science 241: 1813-1815

Krisko A, Radman M (2013) Phenotypic and genetic consequences of protein damage. PLoS genetics 9

Kumble KD, Ahn K, Kornberg A (1996) Phosphohistidyl active sites in polyphosphate kinase of Escherichia coli. Proceedings of the National Academy of Sciences 93: 1439114395

Lin X, Okuda T, Holzer A, Howell SB (2002) The copper transporter CTR1 regulates cisplatin uptake in Saccharomyces cerevisiae. Molecular pharmacology 62: 1154-1159 Mandic A, Hansson J, Linder S, Shoshan MC (2003) Cisplatin induces endoplasmic reticulum stress and nucleus-independent apoptotic signaling. Journal of Biological Chemistry 278: 9100-9106

Massé E, Gottesman S (2002) A small RNA regulates the expression of genes involved in iron metabolism in Escherichia coli. Proceedings of the National Academy of Sciences 99: 4620-4625

Miyazawa M, Bogdan AR, Tsuji Y (2019) Perturbation of iron metabolism by cisplatin through inhibition of iron regulatory protein 2. Cell chemical biology 26: 85-97. e4 Morrissey JH, Choi SH, Smith SA (2012) Polyphosphate: an ancient molecule that links platelets, coagulation, and inflammation. Blood, The Journal of the American Society of Hematology 119: 5972-5979

Outten FW, Djaman 0, Storz G (2004) A suf operon requirement for Fe-S cluster assembly during iron starvation in Escherichia coli. Molecular microbiology 52: 861-872 
Peleg-Shulman T, Najajreh Y, Gibson D (2002) Interactions of cisplatin and transplatin with proteins: Comparison of binding kinetics, binding sites and reactivity of the Pt-protein adducts of cisplatin and transplatin towards biological nucleophiles. Journal of inorganic biochemistry 91: 306-311

Rachmilovich-Calis S, Masarwa A, Meyerstein N, Meyerstein D (2011) The effect of pyrophosphate, tripolyphosphate and ATP on the rate of the Fenton reaction. Journal of inorganic biochemistry 105: 669-674

Rao NN, Gómez-García MR, Kornberg A (2009) Inorganic polyphosphate: essential for growth and survival. Annual review of biochemistry 78: 605-647

Rao NN, Kornberg A (1996) Inorganic polyphosphate supports resistance and survival of stationary-phase Escherichia coli. Journal of bacteriology 178: 1394-1400

Richter Y, Fischer B (2006) Nucleotides and inorganic phosphates as potential antioxidants. JBIC Journal of Biological Inorganic Chemistry 11: 1063

Rosenberg B, Vancamp L, Krigas T (1965) INHIBITION OF CELL DIVISION IN ESCHERICHIA COLI BY ELECTROLYSIS PRODUCTS FROM A PLATINUM ELECTRODE. Nature 205: 698-9

Rudat AK, Pokhrel A, Green TJ, Gray MJ (2018) Mutations in Escherichia coli polyphosphate kinase that lead to dramatically increased in vivo polyphosphate levels. Journal of

bacteriology 200: e00697-17

Ruiz ON, Alvarez D, Gonzalez-Ruiz G, Torres C (2011) Characterization of mercury bioremediation by transgenic bacteria expressing metallothionein and polyphosphate kinase. BMC biotechnology 11: 82

Sambrook J, Fritsch EF, Maniatis T (1989) Molecular cloning: a laboratory manual. Cold spring harbor laboratory press,

Santos N, Catao C, Martins N, Curti C, Bianchi MdLP, Santos ACd (2007) Cisplatin-induced nephrotoxicity is associated with oxidative stress, redox state unbalance, impairment of energetic metabolism and apoptosis in rat kidney mitochondria. Archives of toxicology 81: 495-504

Seo SW, Kim D, Latif H, O’Brien EJ, Szubin R, Palsson BO (2014) Deciphering Fur transcriptional regulatory network highlights its complex role beyond iron metabolism in Escherichia coli. Nature communications 5: 1-10

Sherman SE, Lippard SJ (1987) Structural aspects of platinum anticancer drug interactions with DNA. Chemical Reviews 87: 1153-1181

Tocheva EI, Dekas AE, McGlynn SE, Morris D, Orphan VJ, Jensen GJ (2013) Polyphosphate storage during sporulation in the gram-negative bacterium Acetonema longum. Journal of Bacteriology 195: 3940-3946

Toso DB, Henstra AM, Gunsalus RP, Zhou ZH (2011) Structural, mass and elemental analyses of storage granules in methanogenic archaeal cells. Environmental microbiology 13: 2587-2599

Touati D, Jacques M, Tardat B, Bouchard L, Despied S (1995) Lethal oxidative damage and mutagenesis are generated by iron in delta fur mutants of Escherichia coli: protective role of superoxide dismutase. Journal of bacteriology 177: 2305-2314

Williams KM, Rowan C, Mitchell J (2004) Effect of amine ligand bulk on the interaction of methionine with platinum (II) diamine complexes. Inorganic chemistry 43: 1190-1196 Xie L, Jakob U (2019) Inorganic polyphosphate, a multifunctional polyanionic protein scaffold. Journal of Biological Chemistry 294: 2180-2190 
Xie L, Rajpurkar A, Taube N, Quales E, Erba J, Rai AS, Sliwinski B, Markowitz M, Jakob U, Knoefler D (2019) Accumulation of Nucleolar Inorganic Polyphosphate Is a Cellular Response to Cisplatin-Induced Apoptosis. Frontiers in Oncology 9: 1410 Yang Z, Schumaker LM, Egorin MJ, Zuhowski EG, Guo Z, Cullen KJ (2006) Cisplatin preferentially binds mitochondrial DNA and voltage-dependent anion channel protein in the mitochondrial membrane of head and neck squamous cell carcinoma: possible role in apoptosis. Clinical cancer research 12: 5817-5825

Zheng LL, Huang CZ (2014) Selective and sensitive colorimetric detection of stringent alarmone ppGpp with Fenton-like reagent. Analyst 139: 6284-6289 
bioRxiv preprint doi: https://doi.org/10.1101/2020.04.14.040345; this version posted April 15, 2020. The copyright holder for this preprint (which was not certified by peer review) is the author/funder, who has granted bioRxiv a license to display the preprint in perpetuity. It is made available under aCC-BY-NC-ND 4.0 International license.

\section{Figure 1}

A

untreated

wt

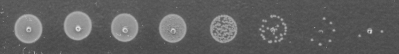

$\triangle p p k$

$0000 \%:$

$\Delta p p x$

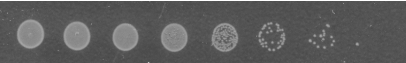

B

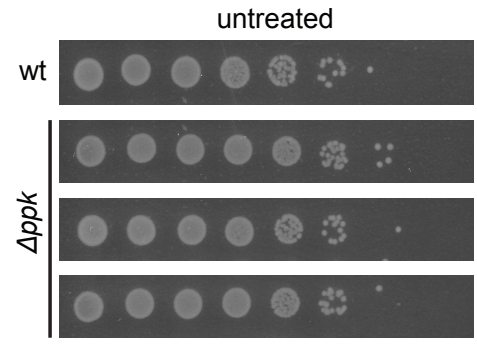

cisplatin

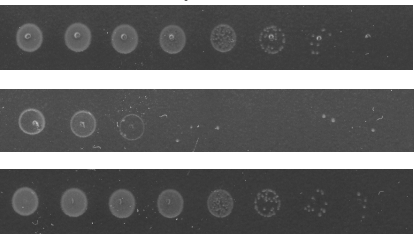

cisplatin

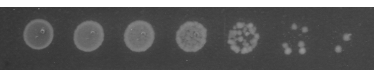

00 \& 10.

00000 है०

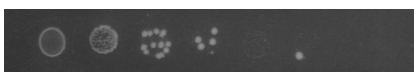

C

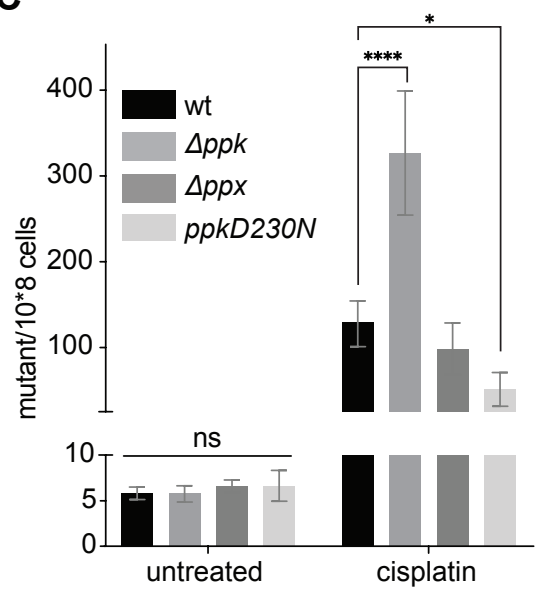


bioRxiv preprint doi: https://doi.org/10.1101/2020.04.14.040345; this version posted April 15, 2020. The copyright holder for this preprint (which was not certified by peer review) is the author/funder, who has granted bioRxiv a license to display the preprint in perpetuity. It is made available under aCC-BY-NC-ND 4.0 International license.

\section{Figure 2}

A

$$
\text { SOS response }
$$

nitrate assimilation

iron-sulfur cluster
assembly

sulfur metabolism

anaerobic ETC

sulfate assimilation

histidine biosynthesis

response to copper

enterobactin

phosphate starvation

fermentation

iron-sulfur cluster

protein maturation

heme transport

phosphate transport

maltodextrin transport

arginine catabolism

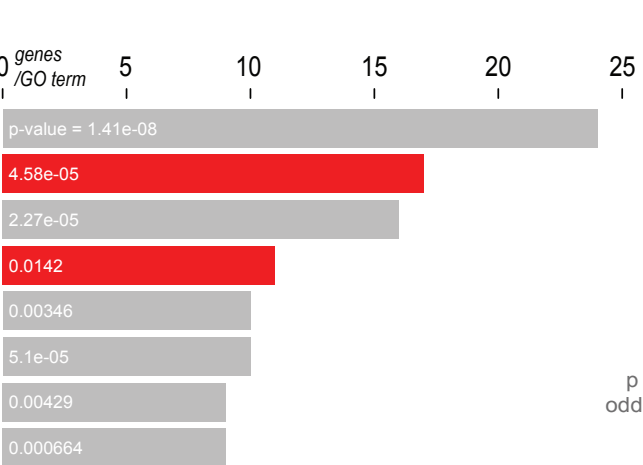

wt / cisplatin

0.000584

0.00599

0.00193

0.00629

0.00629

0.0199

B

phosphate transport

peptide transport

glycine decarboxylation

hydrogen sulfide
biosynthesis

phosphate starvation

dipeptide transport

sulfate assimilation

lysine biosynthesis

nitrogen fixation
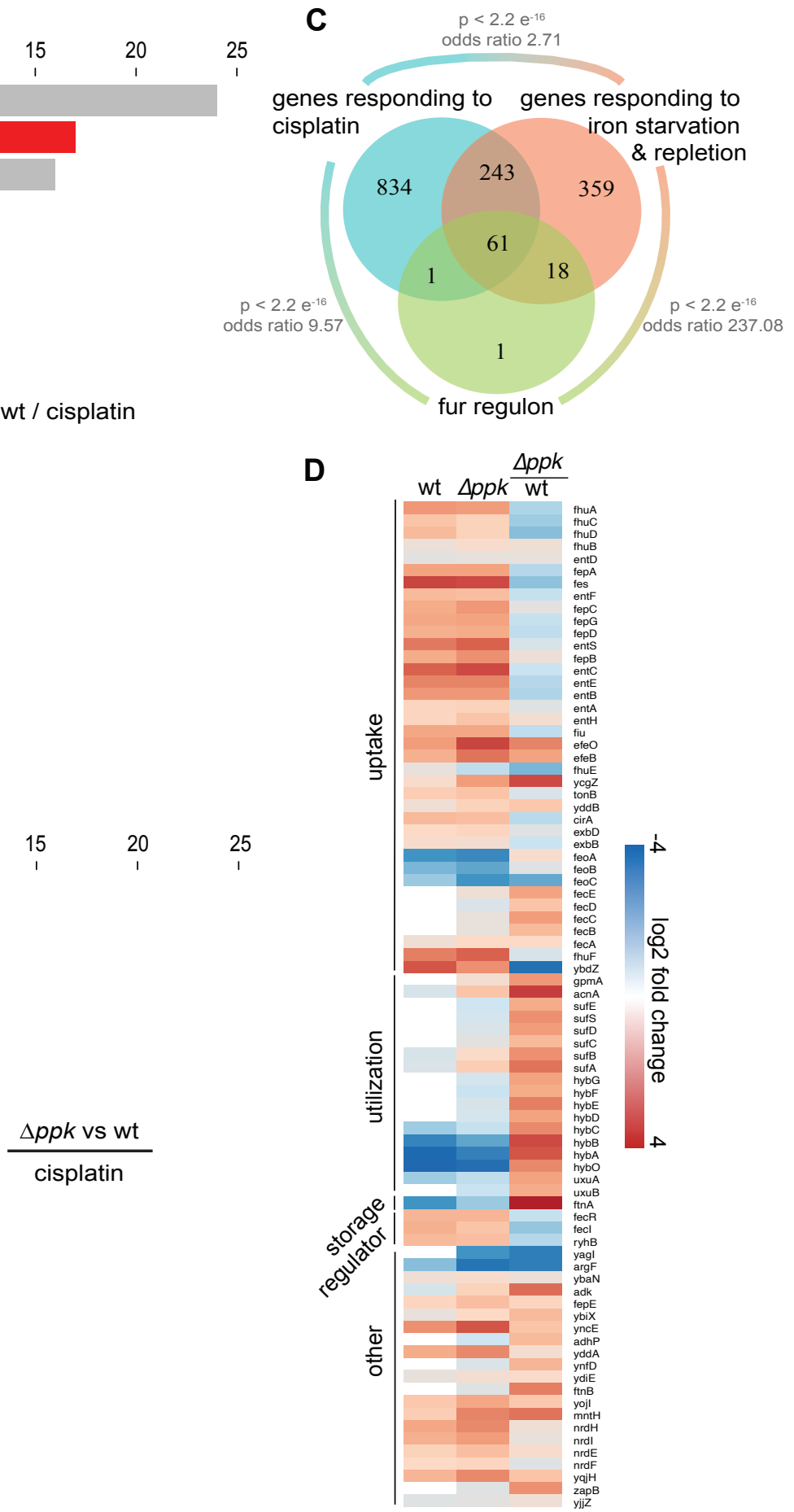
bioRxiv preprint doi: https://doi.org/10.1101/2020.04.14.040345; this version posted April 15, 2020. The copyright holder for this preprint (which was not certified by peer review) is the author/funder, who has granted bioRxiv a license to display the preprint in perpetuity. It is made available under aCC-BY-NC-ND 4.0 International license.

\section{Figure 3}

A

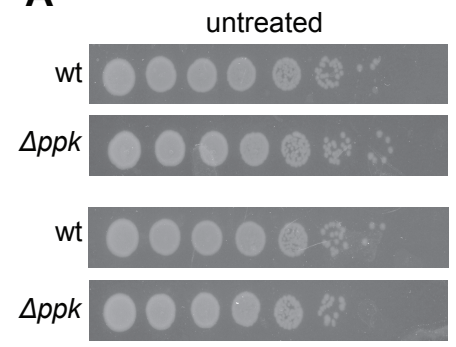

C

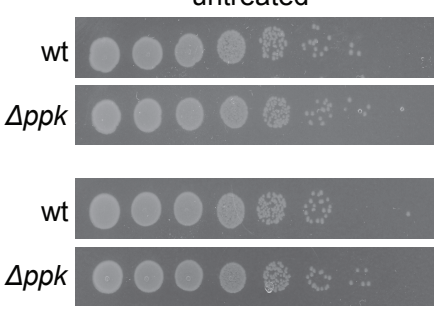

E

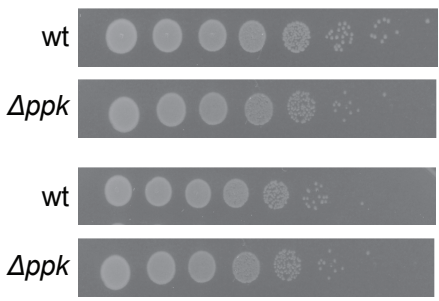

cisplatin

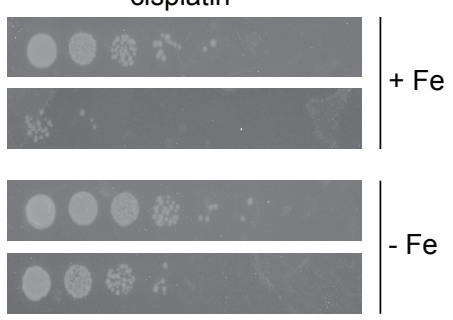

cisplatin
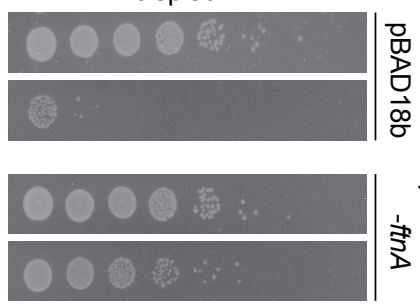

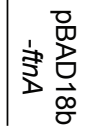

cisplatin

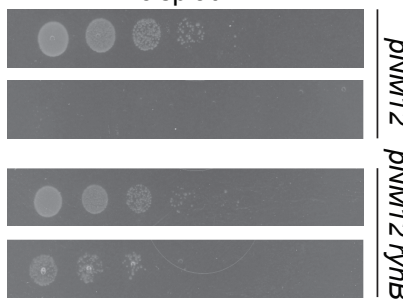

B
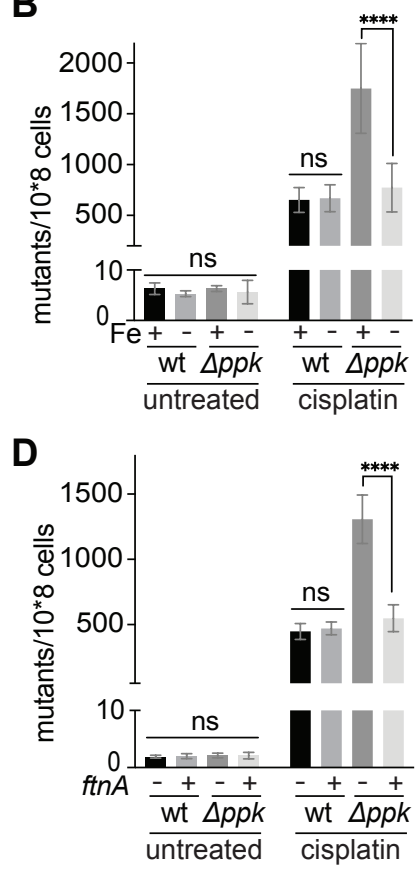

$\mathbf{F}$

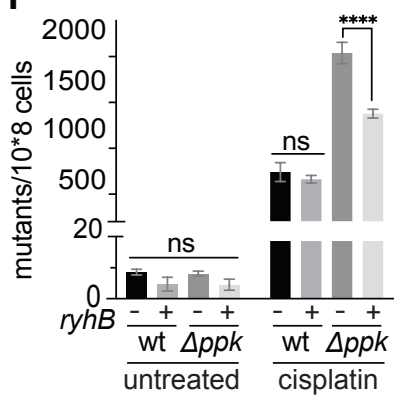


bioRxiv preprint doi: https://doi.org/10.1101/2020.04.14.040345; this version posted April 15, 2020. The copyright holder for this preprint (which

was not certified by peer review) is the author/funder, who has granted bioRxiv a license to display the preprint in perpetuity. It is made available under aCC-BY-NC-ND 4.0 International license.

Figure 4

A

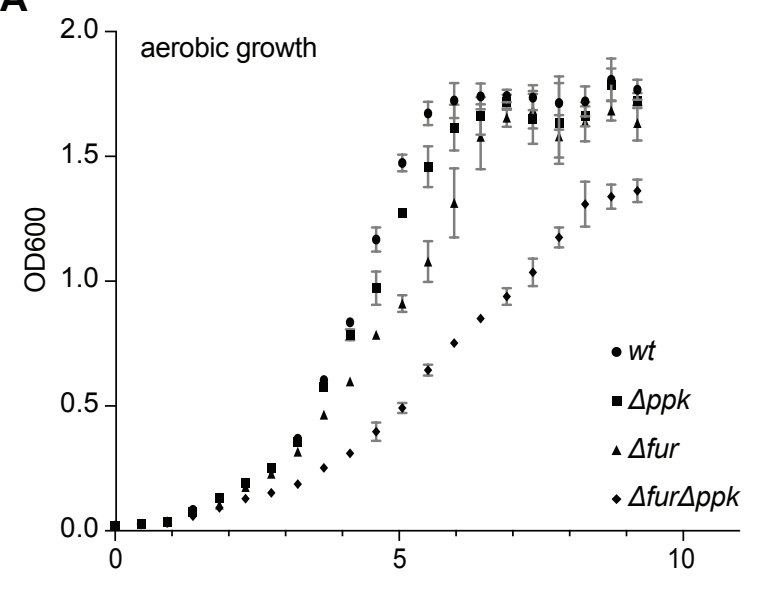

C

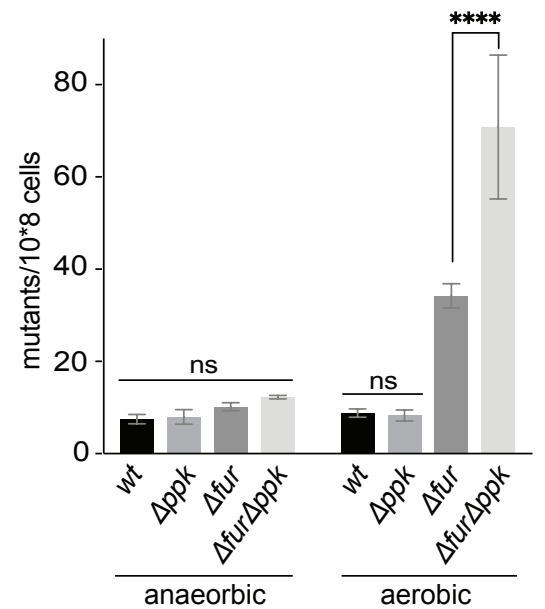

B

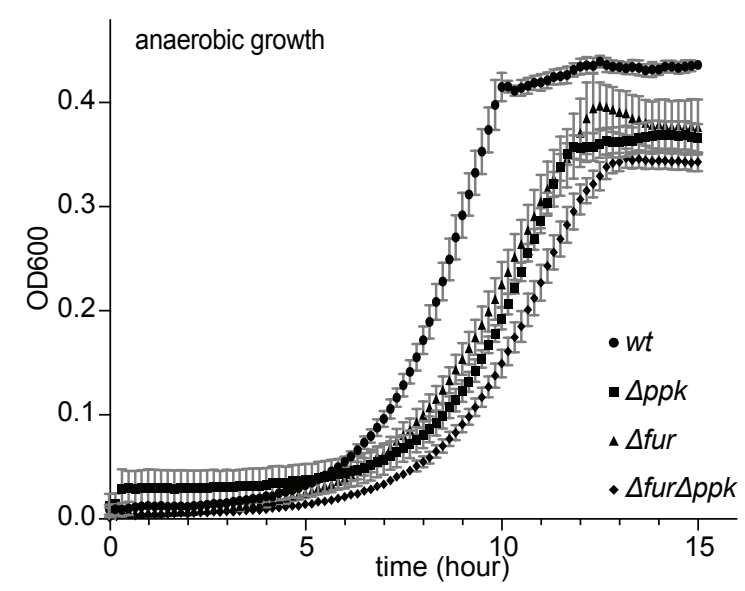

D

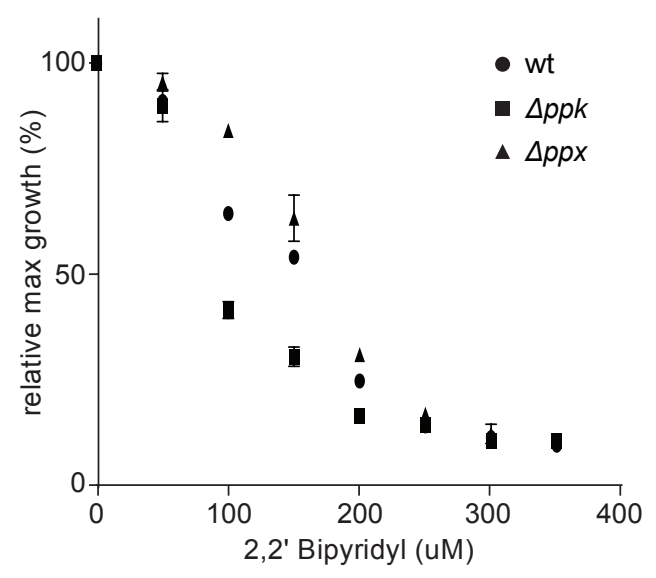


bioRxiv preprint doi: https://doi.org/10.1101/2020.04.14.040345; this version posted April 15, 2020. The copyright holder for this preprint (which was not certified by peer review) is the author/funder, who has granted bioRxiv a license to display the preprint in perpetuity. It is made available under aCC-BY-NC-ND 4.0 International license.

Figure 5

A
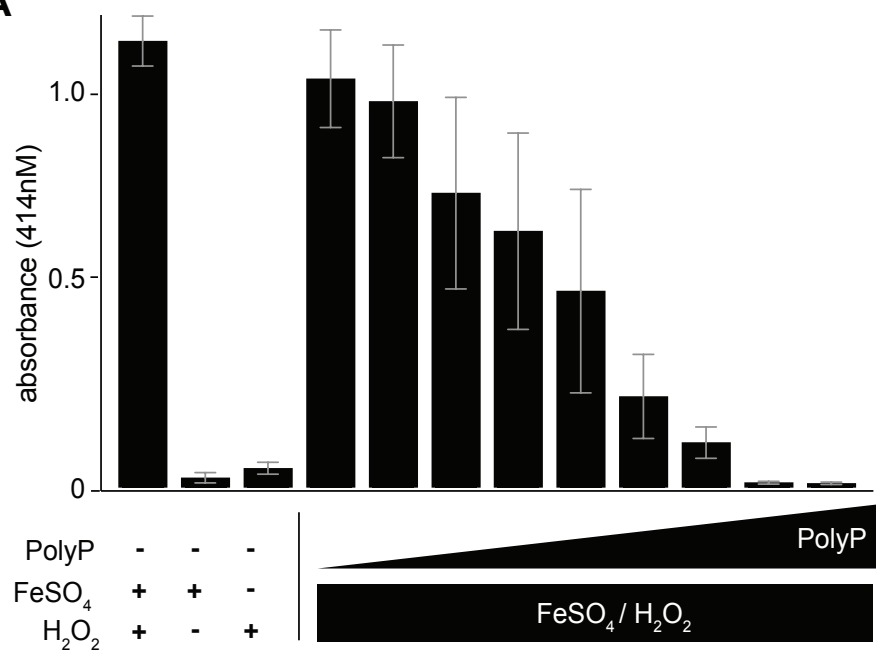

B

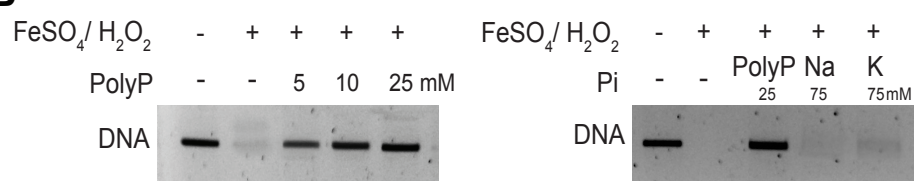


bioRxiv preprint doi: https://doi.org/10.1101/2020.04.14.040345; this version posted April 15, 2020. The copyright holder for this preprint (which

was not certified by peer review) is the author/funder, who has granted bioRxiv a license to display the preprint in perpetuity. It is made available under aCC-BY-NC-ND 4.0 International license.

\section{Figure 6}

A

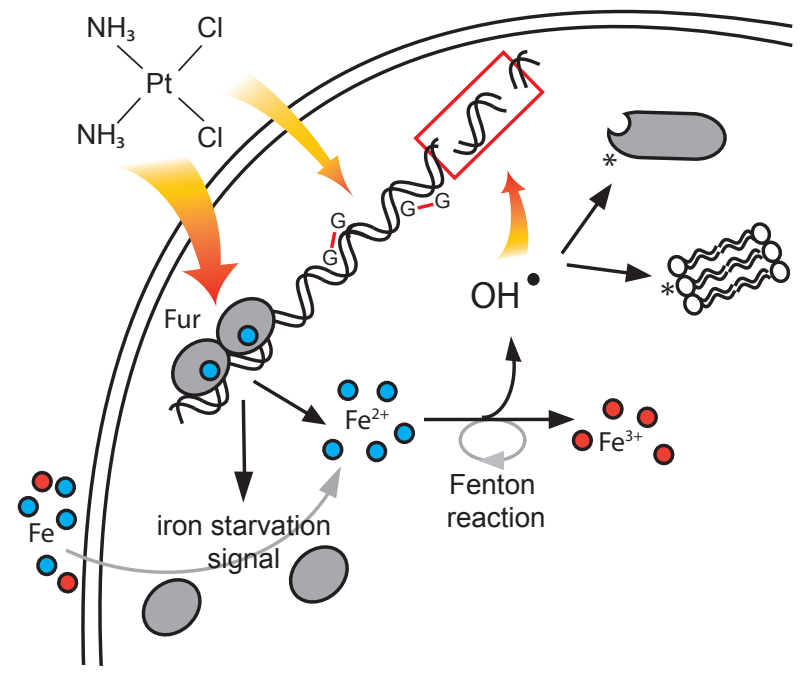

B

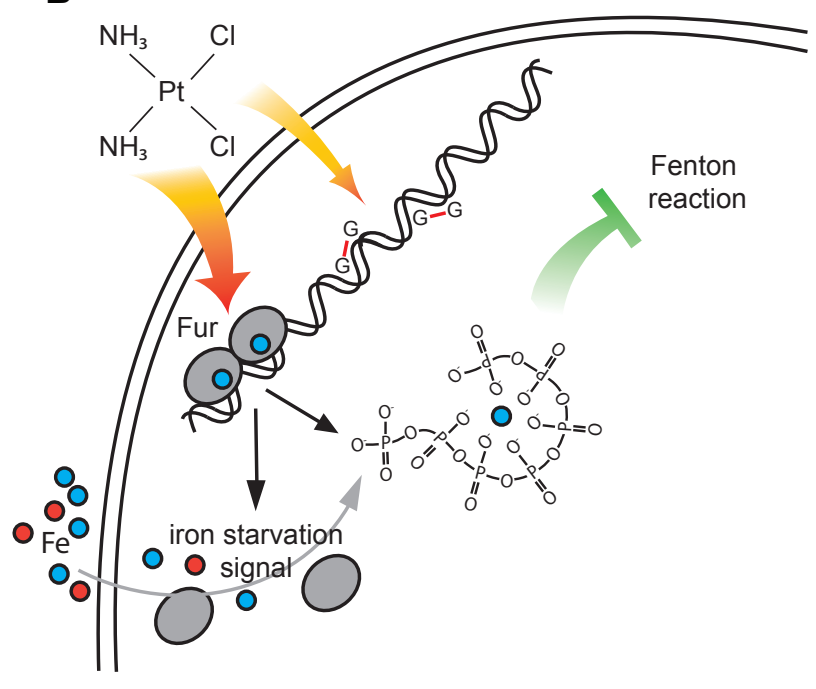

